ROCZNIKI NAUK PRAWNYCH

Volume XXVIII, number 3 - 2018

E n g $1 \mathrm{ish}$ ve r s i o n

DOI: http://dx.doi.org/10.18290/rnp.2018.28.3-11en

\title{
THE CONCEPT OF RELICS AND CANONICAL RECOGNITION, TRANSFER AND PRESERVATION OF THE MORTAL REMAINS OF SERVANTS OF GOD ACCORDING TO THE INSTRUCTION OF THE CONGREGATION FOR THE CAUSES OF SAINTS OF 8 DECEMBER 2017
}

\section{INTRODUCTION}

From the moment when Pope Francis (during an audience given to the Secretary of State) approved the Norms regarding the administration of temporal goods in the causes of beatification and canonization ${ }^{1}$ on March 4, 2016, and when six months later (August 24, 2016), authorised by Pope Francis, the same Secretary of State, Cardinal Pietro Parolin approved the new Rules of the Medical Boar ${ }^{2}$-it is apparent that the reform of canonization law has commenced and that the rate at which documents on these matters are issued has accelerated greatly. In the following year, in his apostolic letter issued motu proprio Maiorem hac dilection On the Offer of

Lidia Fiejdasz-BuczeK, PhD, is an assistant professor at the Department of Canonization Law and Sacramental Law, Institute of Canon Law, Faculty of Law, Canon Law and Administration of the John Paul II Catholic University of Lublin (KUL); address: Al. Racławickie 14, 20 950 Lublin, Poland; e-mail: lfiejda@kul.lublin.pl; https://orcid.org/0000-0001-6252-4027.

${ }^{1}$ Congregation for the Causes of Saints, Norme sull'amministrazione dei beni delle cause di beatificazione e canonizzazione, March 10, 2016, AAS 108 (2016), 495-98; English translation available on http://www.vatican.va/roman_curia/congregations/csaints/documents/rc_ con_csaints_doc_20160307_norme-beni-cause_en.html; Polish translation in "Normy dotyczące administrowania funduszami przeznaczonymi na prowadzenie spraw beatyfikacyjnych i kanonizacyjnych (7.03.2016)," trans. M. Bider and H. Misztal, in H. MiszTal and L. FiejDasz-BuczeK, Postępowanie kanonizacyjne $w$ diecezji lub eparchii (Lublin: Wydawnictwo KUL, 2017), 273-78 [henceforth quoted as: Postępowanie kanonizacyjne].

${ }^{2}$ IDEM, Rules of the Medical Board of the Congregation for the Causes of Saints, September 23, 2016, AAS 108 (2016): 1004-9; English translation available on https://press.vatican.va/content /salastampa/en/bollettino/pubblico/2016/09/23/160923a.html. 
Life, ${ }^{3}$ Pope Francis established a new measure of holiness, and on December 5, 2017, he approved the Instruction Relics in the Church: Authenticity and Preservation. ${ }^{4}$ On April 9, 2018, Holy Father's theological document on holiness was presented-the apostolic exhortation Gaudete et Exsultate on the call to holiness in today's world. ${ }^{5}$ It seems, then, that within two years Pope Francis promulgated or ordered the promulgation of as many legal acts on canonization causes as John Paul II did during his almost 27-year-long pontificate.

In this dynamically changing reality, my choice of this subject seems justified. The instruction on the relics, despite announcements, has not been officially translated into Polish yet (as of July 30, 2018), nor has a scientific commentary been provided. ${ }^{6}$

\section{LEGAL FORCE}

The document has the status of an instruction. It explains the regulations of the laws, develops and defines the rationale to be considered when observing them. The provisions of the instruction do not change the laws, and if they cannot be reconciled with those provisions, they have no force whatsoever (c. 34, $\$ 1$ and 2 CIC/83). The instruction Relics in the Church: Authenticity and Preservation replaced ${ }^{7}$ the appendix to the instruction Sanctorum Mater for conducting diocesan or eparchial inquiries in the

\footnotetext{
${ }^{3}$ Franceso, Apostolic Letter issued Motu Proprio "maiorem hac dilectionem" on the offer of life, Bollettino, July 11, 2017, no. B0484; English translation available on https://press.vatican.va/ content/salastampa/en/bollettino/pubblico/2017/07/11/170711a.html.

${ }^{4}$ Congregation fOR the Causes of Saints, Relics in the Church: Authenticity and Preservation, Bollettino, December 16, 2017; English translation available on http://www.vatican.va /roman_curia/congregations/csaints/documents/rc_con_csaints_doc_20171208_istruzione-reliquie _en.html [henceforth abbreviated as IR].

${ }^{5}$ FrANCIS, Apostolic Exhortation Gaudete et Exsultate of the Holy Father Francis on the call to holiness in today's world, March 19, 2018. English translation available on http://w2.vatican.va/ content/francesco/en/apost_exhortations/documents/papa-francesco_esortazione-ap_20180319_gau deteet-exsultate.html. See also "La santitá nel mondo di oggi. Presentata l'esortazione apostolica «Gaudete et exsultate»," L'Osservatore Romano, April, 9-10, 2018, p. 1.

${ }^{6}$ Congregation for the Causes of Saints, Le Cause dei Santi. Sussidio per lo Studium, ed. V. Criscuolo, C. Pellegrino, and R. Sarno, preface by A. Amato, $4^{\text {th }}$ ed. (Vatican City: Libreria Editrice Vaticana, 2018), 225-47.

${ }^{7}$ C. $34, \S 3 \mathrm{CIC} / 83$ : "Instructions cease to have force not only by explicit or implicit revocation of the competent authority who issued them or of the superior of that authority but also by the cessation of the law for whose clarification or execution they were given."
} 
Causes of Saints. ${ }^{8}$ The instruction on relics in the Church was approved by the Pope Francis on December 5, 2017. The text of the instruction, prepared on December 8, 2017 on the Feast of the Immaculate Conception of the Blessed Virgin Mary by the Congregation for the Causes of Saints, signed by the Prefect of the Congregation and its Secretary, was then published in "L'Osservatore Romano" on December 17, 2017 and was given immediate legal force.

\section{THE STRUCTURE OF THE DOCUMENT AND ITS ADDRESSEES}

The Instruction contains 38 articles (and is much more comprehensive than the previous one, in which the Appendix contained 15 articles). It is preceded by an extensive introduction and divided into 3 parts: I. Request for the Consent of the Congregation for the Causes of Saints. II. Diocesan or Eparchial Phase of the possible specific procedures. III. Pilgrimage of the Relics. Part II includes three titles (I. Initial Acts II. The Specific Procedures III. Final Acts). Title II, The Specific Procedures, encompasses three chapters: I. Canonical Recognition II. Extraction of Fragments and Creation of Relics III. Translation of the Urn and Alienation of Relics. The Instruction concludes that the resolution of all other issues is left to the judgement of the bishop or the episcopal delegate.

The instruction is addressed to those responsible for the execution of laws and who are bound by it to implement the laws (c. $34, \S 1 \mathrm{CIC} / 83$ ). In this case, the Instruction is addressed to diocesan bishops, eparchs and those who are equal to them in law. It is also to serve those who participate in the procedures regarding the relics of Blessed and Saints, and in the procedures concerning the mortal remains of Servants of God and Venerables (that is members of the beatification and canonization tribunals, postulators and others) to facilitate the application of what is required in such special matters.

\footnotetext{
${ }^{8}$ Congregation for the CAUSes of SAInTs, Instruction Sanctorum Mater for conducting diocesan or eparchial inquiries in the causes of saints, December 16, 2006, AAS 99 (2007), 465512; English translation available on http://www.causesanti.va/content/causadeisanti/it/documenti/sanctorum-materen.html.
} 


\section{THE CONCEPT OF RELICS-HISTORICAL CONDITIONING}

It is a good thing that the Congregation for the Causes of Saints has precisely organised the terminology related to relics. This was done by making reference to the historical division that had already existed in the practice of the Congregation of Rites, ${ }^{9}$ which was appointed in 1588 by Sixtus V (15851590), and later also in the practice of the Congregation for Indulgences and Relics, which was part of the structure of the Roman Curia in the years 1669-1904. If we analyse decrees from those years, we quickly realize that it was important whether relics were significant (reliquie insigni) or insignificant (reliquie non insigni). For example, in the decree of the Congregation of Rites dated April 8, $1628^{10}$ it was specified that significant relics were: the body, head, arm, leg, or other part of the body by reason of which a martyr suffered as long as it was not too small and had the bishop's approval. ${ }^{11}$ In 1899, the Congregation of Rites, having asked the opinion of the experts of the Liturgical Commission, declared that a significant relic was also: a separate part of an arm that precedes the forearm; the outer part of the arm, and also: the heart, tongue, hand, if miraculously preserved. ${ }^{12}$

In contrast, pieces of bones from the head of St Stephen were not relics, as expressed by the Congregation of Rites in the decree of December 20, $1628,{ }^{13}$ nor was a fragment of St Lawrence's foot (an external fragment of

\footnotetext{
${ }^{9}$ SIXTUS V, Costituzione apostolica Immensa aeterni Dei Istituzione di quindici Congregazioni, di cui la quinta pro sacris ritibus et caeremoniis, January 22, 1588, in Leggi della Chiesa su beatificazione e canonizzazione dall'anno 993 all'anno 2000. Collezione, ed. L. Porsi (Rome: Nova Res, 2006), 97-98 [henceforth quoted as Leggi della Chiesa]; P. PALAZZINI, "Le congregazione romane," in La Curia Romana nella Cost. Ap. «Pastor Bonus», ed. P.A. Bonnet and C. Gullo (Vatican City: Libreria Editrice Vaticana, 1990), 189.

${ }^{10}$ SaCred Congregation of Rites, Urbis, June 8, 1628, in Ab anno 1588 num. 1 usque ad annum 1705 num. 2162. Vol. 1 of Decreta autentica Congregationis Sacrorum Rituum ex actis eiusdem collecta eiusque autoritatae promulgata sub auspicii ss. Domini Nostri Leonis Papae XIII (Rome 1898), 118.

11 "Insignes autem Reliquias declaravit esse Corpus, Caput, Brachium, Crus, aut illam partem corporis in qua passus est Martyr, modo sit integra et non parva, et legitime ab Ordinariis approbata," see SACRED CONGREGATION OF RITES, Urbis, June 8, 1628 (Rome: Typrographia polyglotta S. C. da propaganda ficha), no. 3, p. 118.

${ }^{12}$ SaCRed Congregation OF Rites, Urbis et Orbis, June 27, 1899, in Ab anno 1871 num. 3233 usque ad annum 1899 num. 4051, vol. 3 of Decreta autentica Congregationis Sacrorum Rituum ex actis eiusdem collecta eiusque autoritatae promulgata sub auspicii ss. Domini Nostri Leonis Papae (Rome: Typrographia polyglotta S. C. da propaganda ficha, 1900), 368.

${ }^{13}$ IDEM, Baren, December 20, 1628, in Decreta autentica, 1: 124
} 
the left leg with four fingers covered with flesh). ${ }^{14}$ This division into significant and insignificant relics had some consequences. For example, ordinaries were forbidden to celebrate Mass and feasts with an office of a saint if no significant relic was kept in the church, ${ }^{15}$ or it was not possible to include the Creed ${ }^{16}$ in Mass; nor could insignificant relics be carried in procession.

The Code of Canon Law of 1917 adopted the same division, emphasizing in canon 1281, $\$ 2$ that significant relics were: "the whole body, head, shoulder, forearm, heart, tongue, hand, shin or that part of the body by reason of which the martyr suffered, as long as it is not too small or too small." 17 $\mathrm{CIC} / 17$ prohibited the storage of significant relics in private homes and oratories without a written permission of the ordinary of the place (c. 1282, §1). The code permitted this for insignificant relics, without defining them.

The 1983 Code of Canon Law does not contain a definition of relics. However, it strongly prohibits the alienation of significant relics (insignes reliquiae) and others held in great veneration by the faithful without the permission of the Holy See (c. 1190). This definition was also not included in the Appendix to the Instruction Sanctorum Mater of May 17, 2007.

It was not until the instruction of the Congregation for the Causes of Saints of December 8, 2017 that significant relics were declared to be: 1) the bodies of saints and blessed, or 2) their notable parts, or 3) the total sum of the ashes obtained by their cremation (Introduction). Certified as authentic they are to be stored with respect in properly sealed urns (coffins), placed in dignified places that guarantee safety, a sacred atmosphere and facilitate worship (Introduction).

The following are considered to be insignificant relics: 1) small fragments of the body of blesseds and saints or 2) objects that were in direct contact with those persons (Introduction). In addition, it was decided that one could speak of relics only after the beatification. Thus the instruction

\footnotetext{
${ }^{14}$ IDEM, Patavina, December 7, 1844, ad. 1, in Ab anno 1706 num. 2163 usque ad annum 1870 num. 3232, vol. 2 of Decreta autentica Congregationis Sacrorum Rituum ex actis eiusdem collecta eiusque autoritatae promulgata sub auspicii ss. Domini Nostri Leonis Papae XII (Rome: Typrographia polyglotta S. C. da propaganda ficha, 1898), 323.

${ }^{15}$ IDEM, Urbis, December 8, 1628, 118.

${ }^{16}$ IDEM, Patavina, December 7, 1844, ad. 1, p. 323. For more on this, see L. FIEJDASZ, "Kształtowanie się pojęcia relikwii: aspekt prawny," in Kult relikwii, ed. Sz.T. Praśkiewicz, vol. 11 of Świętość Kanonizowana (Kraków: Wydawnictwo Karmelitów Bosych, 2013), 17-38 [henceforth quoted as.: ŚK, vol. 11].

17 "Insignes Sanctorum vel Beatorum reliquiae sunt corpus, caput, brachium, antibrachium, cor, lingua, manus, crus aut illa pars corporis in qua passus est martyr, dummodo sit integra et non parva."
} 
dispelled doubts of those who thought that significant relics were any objects touched by the blessed, or small pieces of bones or blood. Despite the ban expressed in c. 1090, $\$ 1 \mathrm{CIC} / 83$, various insignificant relics are sold on the Internet. The Congregation for the Causes of Saints reminds us that these insignificant relics in any case are to be preserved and honoured in a religious spirit, avoiding every type of superstition or illicit trade (Introduction), and Article 25 of the Instruction expressly forbids the exchange of relics for something else or for money and the sale of relics (that is, the transfer of relics at a certain price). It is forbidden to exhibit relics in profane or unauthorised places.

\section{THE COMPETENT AUTHORITY AND ACTS PRECEDING THE CANONICAL RECOGNITION OF MORTAL REMAINS OF SERVANTS OF GOD}

The goal of canonical recognition of the mortal remains of a Servant of God is to establish their authenticity. More precisely, we should remember that neither the apostolic constitution Divinus perfectionis Magister of January $25,1983^{18}$ nor its implementing norms - Normae servandae of February $7,1983^{19}$ settled anything on the canonical recognition of the mortal remains of the Servant of God. ${ }^{20}$ This was done only by the Congregation for the Causes of Saints in the instruction for conducting diocesan or eparchial inquiries in the causes of saints Sanctorum Mater of May 17, 2007, ${ }^{21}$ which noted in Article 141 that: "Before proceeding to the definitive closing of the Inquiry, the diocesan or eparchial Bishop may proceed to the canonical recognition of the mortal remains of the Servant of God," specifying in Article $2, \S 1$ of the no longer binding appendix that "it is necessary to certify that

\footnotetext{
${ }^{18}$ JoHn PAUL II, Apostolic constitution Divinus perfecionis Magister, January 25, 1983, AAS 75 (1983), 349-55. English translation available on http://w2.vatican.va/content/john-paulii/en/apost_constitutions/documents/hf_jp-ii_apc_25011983_divinus-perfectionis-magister.html.

${ }^{19}$ CONGREgation for the CAuses of SAINTS, Norms to be observed in inquiries made by bishops in the causes of saints, February 7, 1983, AAS 75 (1983), 396-403; English translation available on http://www.causesanti.va/content/causadeisanti/it/documenti/normae-servandae_en.html.

${ }^{20}$ For more on this, see H. MiszTal, Prawo kanonizacyjne. Instytucje prawa materialnego, zarys historii, procedura, 2nd ed. (Lublin: Wydział Prawa, Prawa Kanonicznego i Administracji KUL, Sandomierz: Wydawnictwo Diecezjalne, 2003), 387.

${ }^{21}$ Congregation FOR THE CAuSes of SAINTs, Sanctorum Mater. Instruction For Conducting Diocesan or Eparchial Inquiries in the Causes of Saints, December 16, 2006, AAS 99 (2007), 465-517; Communicationes 39, no. 2 (2007): 221-68.
} 
the mortal remains of a Servant of God whose cause is in progress are authentic," "before the Inquiry is closed" (Article 3 of the Appendix).

The bishop of the diocese or the eparchy in which the mortal remains are preserved is competent to carry out all possible procedures related to them. ${ }^{22}$ The optional request for instructions from the Congregation to carry out canonical recognition of mortal remains ${ }^{23}$ was replaced by the obligatory consent of the same dicastery.

The provision of the second part of Article 2 of the Instruction on Relics is novel, whereby before performing any procedure on mortal remains, all provisions of the local civil law are to be observed, ${ }^{24}$ and the heir's consent must be obtained in accordance with them. Also before the beatification, such consent must be obtained from the heir for the donation of the body fragments to the Church (Art. 2, §2). In the Polish law, one is made eligible for inheritance by a will or statute - if the testator has not appointed an heir or when none of the persons he or she has appointed wants or can be an heir (Art. 926, $\S \S 1-2$ of the Polish Civil Code). The circle of heirs, be it testamentary or statutory ones, is not the same as the circle of those entitled to bury (and exhume) a corpse. According to Article 10 para. 1 of the Act of 31 January 1959 on cemeteries and burying the dead, ${ }^{25}$ this right is vested in the immediate living family of the deceased, that is: 1) the living spouse, 2) a descendant relative, 3) an ascendant relative, 4) a lateral relative up to the fourth degree of consanguinity, and 5) a person related by kinship in a straight line up to the first degree. Should therefore permission be asked only of the testamentary or statutory heirs? What if the heir is a person from outside the immediate living family? Or when the estate was inherited by an institution, like the State Treasury? Should the immediate family at least not be informed about the planned actions in such a situation? Will the lack of consent of the immediate family members enumerated in Article 10 para. 1 of the Act on cemeteries and burying the dead not adversely affect the climate associated with the ongoing beatification process? Disregarding the consent of the immediate family of the deceased constitutes an infringement of the

\footnotetext{
${ }^{22}$ Art. 1 IR: "The one competent to perform all the possible procedures on relics or on mortal remains is the Bishop of the diocese or of the eparchy where they are preserved, if he has obtained beforehand the consent of the Congregation for the Causes of the Saints." See also Art. 7 IR.

${ }^{23}$ Compare Art. 4, $\S 1$ of the Appendix to Sanctorum Mater.

${ }^{24}$ The Italian term "legge civile locali", appearing very often in official documents of the Catholic Church, should be translated not as "civil law," but as "secular law" to distinguish it from canon law.

${ }^{25}$ The uniform text published in: Journal of Laws of 2015, item 2126.
} 
personal right to bury the corpse which does not automatically cease after the funeral is complete, and its scope also includes cases when exhumation is demanded in order to bury the corpse in another suitable place. ${ }^{26}$ No matter which option is chosen prudently in a specific case, in the event of disagreement among the family members as to exhumation, the court of law is competent to resolve this matter. ${ }^{27}$ These are not purely academic considerations. On June 8, 2018, the New York Supreme Court adjudicated a long-lasting dispute between the Diocese of Peoria and the Archdiocese of New York over the exhumation and translation of Archbishop Fulton Sheen's body from St Patric's Cathedral in New York to the Diocese of Peoria, which conducted his beatification process. ${ }^{28}$ Judge Arlene Bluth argued that "Joan Sheen Cunningham, the niece and closest living relative of Archbishop Sheen, met the legal conditions necessary to exhume her uncle's body" and that the expected canonization is a sufficient reason for the transfer of the mortal remains of Archbishop Scheen. ${ }^{29}$

Having the above-mentioned consent, the competent bishop asks the Congregation for the consent to perform the activities he intends to carry out (Art. 3, §1 IR). In a written request, he describes in detail: 1) the place where the remains are currently preserved (city, church name, chapel, public or private cemetery, etc.) (Art. 3, §2 IR); 2) place of final burial, including a plan of the new location of the grave (indicating the city, name of the church, chapel, cemetery, etc.) - if the transfer is to be final to a different new location in the diocese of eparchy (Art. 4, §1 IR); 3) the place of the final burial, with a plan of the new location attached and the receiving bishop's written consent regarding the party that will be endowed with the

\footnotetext{
${ }^{26}$ See also the Decision of the Supreme Court of 13 January 1965, file ref. no. I CR 464/64, LEX no. 259; A. PARTYK, Pierwszeństwo osób wymienionych w art. 10 ust. 1 ustawy o cmentarzach $i$ chowaniu zmartych, do pochówku zwłok $w$ określonym grobie oraz do ekshumacji, LEX/el., 2014. It is also worth noting that there is no unanimity in Polish jurisprudence as to whether the persons mentioned in Article 10 para. 1 of the said Act have a sort of "priority" in respect of burial, whether the burial requires an unanimous cooperation of all persons who are close to the deceased, or whether each of these persons may independently undertake actions while the others may oppose this when the action has the attributes of an unlawful act. For more on this, see Postepowanie kanonizacyjne, 196-97.

${ }^{27}$ E. DARMOROST, Ustawa o cmentarzach i chowaniu zmartych. Komentarz (Warsaw 2014), LEX/el.

${ }^{28}$ V. Criscuolo, "Praenotatio Relatoris Generalis," in Congregation for the Causes of SAINTS, Peorien. Beatificationis et Canonizationis Servi Dei Fulton Ioannis Sheen Archiepiscopi Titularis Neoportensis Episcopi Roffensis in America (1895-1979). Positio super vita, virtutibus et fama sanctitatis (Rome: Tipografiia Nova Res s.r.1., 2011), 1: I-VI.

29 "Wyrokiem Sądu Najwyższego w Nowym Jorku ciało Arcybiskupa Sheena może zostać przeniesione do Peorii," accessed July 18, 2018, https://abpsheen.pl.
} 
mortal remains - in the case of translation to another diocese (Art. 4, §2 IR), the bishop always confirms that he has obtained the heir's consent. If the mortal remains are to be alienated within the same diocese or eparchy, the competent bishop should send the Congregation a copy of the written consent of the parties: the alienating party and the future owner. In the event of alienation to another diocese or parish, the request is accompanied by a copy of the written consent of the bishop (ad quem), who is going to receive the relics, the written consent of the alienating party and the future owner, as well as a plan of the new location (Art. 5 IR).

After receiving the rescript of the Congregation, the bishop may proceed according to the instructions of this dicastery, ${ }^{30}$ scrupulously, avoiding any sign of unlawful cult to a Servant of God or a Venerable Servant of God who has not yet been beatified yet (Art. 6 IR). ${ }^{31}$

The bishop establishes a tribunal, nominating by decree those who will perform the functions of the episcopal delegate, promoter of justice, and notary (Art. 8 IR). He also appoints: an expert doctor (anatomical pathologist, medical examiner or other specialist) and, if necessary, an assistant to the expert doctor (autopsy technician), as well as others to carry out the technical work. He appoints at least two faithful (priests, consecrated persons, lay persons) who sign the documents as witnesses (Art. 10 IR). In the previous practice, before the exhumation, at least two witnesses to the funeral and burial of the Servant of God had to be questioned under oath about the authenticity of the grave. ${ }^{32}$ The current Instruction does impose this requirement. The participation of a postulator or vice-postulator of the cause is permissible (Art. 11 IR) and of other entities whose presence is deemed appropriate by the bishop or his delegate (Art. 13, §2 IR). However, it is absolutely necessary to avoid publicity surrounding this event (Art. 13, §3 IR), as these activities cannot have the character of a public service. ${ }^{33}$ All those who take part in the canonical recognition of mortal remains must first take an oath to be able to faithfully discharge their duties and to keep the official secret (Art. 12 IR).

\footnotetext{
${ }^{30}$ Examples of such instructions are given in A. Scąber, "Rozpoznanie i zabezpieczenie doczesnych szczątków sług Bożych oraz pobranie relikwii w procedurze beatyfikacyjnej-instrukcje Kongregacji Spraw Kanonizacyjnych i procedura," in ŚK, 11: 72-91.

${ }^{31}$ See also Norms to be observed, no. 36, and Sanctorum Mater, art. 88 and 143.

${ }^{32}$ Misztal, Prawo kanonizacyjne, 388.

${ }^{33}$ Ibid.
} 


\section{CANONICAL RECOGNITION}

The Tribunal and others appointed for this task are to meet on the designated day and time at the place where the remains are preserved (Art. 13, §1 IR). Before their removal, if there exists an authentic document confirming the facts of the last burial, canonical recognition or translation, it should be read out aloud before a notary so that he can verify whether what the content of the document coincides with what now has been established (Art. 14, §1 IR). In the absence of such a document or if the urn or the seals attached thereto appear to be broken, special care must be taken to ensure that they are indeed the mortal remains of the person concerned (Art. 14 IR).

Once the coffin has been extracted, it should be moved to a suitable place (e.g. a forensic clinic, sacristy, etc.). ${ }^{34}$ The mortal remains must be placed on a table covered with dignified cloth so that anatomical experts can clear them of dust and other impurities (Art. 15 IR). Upon completion of these procedures, the experts identify all parts of the body and describe in the most detailed way their condition, and record their conclusions in a joint report, signed by them and attached to the other files (Art. 16 IR). Whenever the canonical recognition reveals the necessity or appropriateness of performing treatments for the preservation of the remains, after obtaining the bishop's consent, such procedures are to be carried out using the most appropriate techniques in places and in the manner indicated by anatomy experts or other experts (Article 17 IR). If the canonical recognition cannot be completed during one session, the place where these operations have been carried out must be locked and secured, and necessary precautions should be taken to avoid theft or profanation. The key is kept by the bishop or his delegate (Art. 18 IR).

When all necessary procedures have been done to preserve the mortal remains and reconstruct the body, everything must be placed into a new urn (Art. 19 IR). If the remains are to be dressed in new robes, these, as far as possible, should retain their previous style (Art. 19, §2 IR). In doing so, the bishop or his delegate are to ensure that no one takes anything out of the urn or puts anything into it (Art. $19 \S 3$ IR). If possible, the old urn and everything

\footnotetext{
${ }^{34}$ The course of these activities is described in detail in G. BARTOSZEWSKI "Ekshumacja i kanoniczne rozpoznanie doczesnych szczątek sługi Bożego w świetle Instrukcji Kongregacji Spraw Kanonizacyjnych 'Sanctorum Mater'," in O Sanctorum Mater, ed. W. Bar and L. Fiejdasz (Lublin: Stowarzyszenie Kanonistów Polskich, 2008), 99-118; "Ekshumacja i zabezpieczenie doczesnych szczątków sług Bożych,” in ŚK, 11: 39-59.
} 
which was found in it is to be religiously preserved, otherwise it must be destroyed (Art. 19, §4 IR).

The record of the operations performed must be placed in a tube bearing the bishop's seal and placed in the urn (Art. 20 IR). If the procedure requires that the mortal remains of the Servant of God are to be transferred within the same diocese or eparchy, the urn should be closed and bound with a ribbon bearing the seal of the bishop, without any solemnity, neither at the place of the previous burial nor at the place of the new burial, avoiding all signs of unlawful cult in accordance with the decrees of Urban VIII on non-cult (Art. 26 IR).

\section{EXTRACTION OF BODY FRAGMENTS AND THE FINAL ACTS}

In the same way as during the canonical recognition of the mortal remains of a Servant of God, it is necessary to proceed with regard to the extraction of body fragments on the occasion of the upcoming beatification of the Servant of God or canonization of the Blessed. Only those body parts which have become naturally detached from the body as indicated by the experts should be collected (Art. 21 IR). The instruction forbids dismembering of the body, unless the bishop has obtained the consent of the Congregation for the Causes of Saints in order to prepare significant relics (Art. 24 IR). The person responsible for drawing up the certificate of authenticity of the relics is the postulator of the cause (Art. 23 IR). ${ }^{35}$ The bishop decides on the place of storage of the extracted fragments (Art. 22 IR).

The notary is to record all procedural acts in a special report signed by the bishop or the episcopal delegate, the promoter of justice, the anatomical experts and the two witnesses mentioned in Articles 9-10 of this Instruction. The notary authenticates the act with his signature and stamp. The Congregation's consent is attached to the report (Art. 28 IR). Reports of all procedures performed, closed and stamped with the seals of the bishop or his delegate, are preserved in the diocesan or eparchial curia, and a copy of it is sent to the Congregation for the Causes of Saints (Art. 29 IR). The new element of the manual is permission to document the course of a canonical recognition and the preservation of temporal remains or relics. In each case, authorised photographs or films of activities should be attached to the report

\footnotetext{
${ }^{35}$ In the absence of postulation, the preparation and signing of the certificate of authenticity of the relics rests with the diocesan bishop, the eparch or ones equivalent to him in law, or their delegates (Art. 23, §2 IR).
} 
and kept with it in the diocesan or eparchial curia (Art. 29, §2 IR). However, photographs and information, originating from anatomical procedures and all treatments, cannot be made public without the consent of the competent bishop and if such exists-without the consent of the heir (Art. 30 IR).

\section{CONCLUSION}

The Congregation for the Causes of Saints, which, in accordance with Article 74 of the Apostolic Constitution Pastor Bonus decides on everything concerning the authenticity and preservation of relics, after the 11 years of applying the Appendix to the Instruction Sanctorum Mater concerning canonical recognition of the mortal remains of a Servant of God, considered it necessary to prepare a new instruction: Relics in the Church: Authenticity and Preservation. In an uncontroversial manner, for the first time since 1983, it systematized the concept of relics, dividing them into significant relics (reliquie insigni) and insignificant ones (reliquie non insigni). Another novelty is the inclusion of the whole volume of the urns with ashes obtained as a result of cremation in the category of significant relics (such used to be the case with a vase containing the blood of martyrs). The Instruction explains in detail all the procedures that are possible to perform on the mortal remains of Servants of God and on relics, emphasising that the diocesan bishop or the eparch must always obtain the consent of the Congregation. It introduces-which is also a novelty in comparison with the previous documents - a requirement to obtain the heirs' consent to perform any actions on the mortal remains (i.e. to exhume, transfer to a different location, or extract body parts before the expected beatification, publish photographs and video material, and other information related to the anatomical procedures), and a requirement to obtain their consent to donate the body fragments to the Church before the beatification. It introduces a requirement that a tribunal be established for canonical recognition of the mortal remains (previously an exhumation commission would be established), and reminds that any signs of unlawful cult should be avoided in accordance with Urban VIII's decrees on non-cult. The Instruction does not specify the exact moment of canonical recognition nor does it refer to Article 141 of Sanctorum Mater. It generally provides that this is to take place before the beatification of a Servant of God. I believe that the Instruction will be of good service to those who face 
the task of canonical recognition of mortal remains and, importantly, it will prevent abuse in the future.

\section{BIBLIOGRAPHY}

\section{SOURCES OF LAW}

Codex Iuris Canonici Pii X Maximi iussu digestus Benediicti Papae XV auctoritatae promulgatus, May 27, 1917. AAS 9 (1917), pars II, 1-593.

Codex Iuris Canonici auctoritate Ioannis Pauli PP. II promulgatus, January 25, 1983. AAS 75 (1983), pars II, 1-317. Polish translation in Kodeks Prawa Kanonicznego, approved by the Polish Episcopal Conference. Poznań: Pallottinum, 1984.

SIXTuS V. Costituzione apostolica Immensa aeterni Dei Istituzione di quindici Congregazioni, di cui la quinta pro sacris ritibus et caeremoniis, January 22, 1588. In Leggi della Chiesa su beatificazione e canonizzazione dall'anno 993 all'anno 2000. Collezione, edited by Luigi Porsi, 97-98. Rome: Nova Res, 2006.

John Paul II. Constitutio apostolica Divinus perfecionis Magister, January 25, 1983. AAS 75 (1983), 349-55. English translation available on http://w2.vatican.va/content/john-paul-ii/en/ apost_constitutions/documents/hf_jp-ii_apc_25011983_divinus-perfectionis-magister.html. Polish translation in Henryk MiszTAL and Lidia Fiejdasz-BuczeK. Postępowanie kanonizacyjne w diecezji lub eparchii, 249-58. Lublin: Wydawnictwo KUL, 2017.

FrANCIS. Lettera apostolica in forma di Motu Proprio del Sommo Pontefice Francesco Maiorem hac dilectionem sull'offerta della vita [Apostolic Letter Issued Motu Proprio "Maiorem hac dilectionem" on the Offer of Life]. Bollettino, July 11, 2017, no. B0484. English translation available on https://press.vatican.va/content/salastampa/en/bollettino/pubblico/2017/07/11/ 170711a.html. Polish translation in "Maiorem hac dilectionem. List apostolski w formie motu proprio o ofiarowaniu życia." L' Osservatore Romano, Polish ed., August 2017, 10-12.

FRANCIS. Esortazione apostolica Gaudete et Exsultate del Santo Padre Francesco sulla chiamata alla santità nel mondo contemporaneo [Apostolic Exhortation Gaudete et Exsultate of the Holy Father Francis on the call to holiness in today's world], March 19, 2018. English translation available on http://w2.vatican.va/content/francesco/en/apost_ exhortations /documents/papafrancesco_esortazione-ap_20180319_gaudete-et-exsultate.html. Polish translation in Adhortacja apostolska Ojca Świętego Franciszka Gaudete et Exsultate. O powołaniu do świętości w świecie wspótczesnym. Kraków: Wydawnictwo M, 2018.

Ustawa o cmentarzach i chowaniu zmarłych z dnia 31 stycznia 1959 r. [Act of 31 January 1959 on cemeteries and burying the dead]. Journal of Laws of 2015, item 2126.

\section{ACTS OF THE CONGREGATION FOR THE CAUSES OF SAINTS}

Congregation for the CAUSes of SAINTS. Normae servandae in inquisitionibus ab Episcopis faciendis in causis sanctorum [Norms to be observed in inquiries made by bishops in the causes of saints], February 7, 1983. AAS 75 (1983), 396-403. English translation available on http://www.causesanti.va/content/causadeisanti/it/documenti/normae-servandae_en.html. Polish translation in Henryk MiszTal and Lidia Fiejdasz-BucZeK. Postepowanie kanonizacyjne w diecezji lub eparchii, 259-69. Lublin: Wydawnictwo KUL, 2017. 
SaCRed Congregation of Rites. Baren, December 20, 1628. In Ab anno 1588 num. 1 usque ad annum 1705 num. 2162. Vol. 1 of Decreta autentica Congregationis Sacrorum Rituum ex actis eiusdem collecta eiusque autoritatae promulgata sub auspicii ss. Domini Nostri Leonis Papae XIII, 124. Rome: Typrographia polyglotta S. C. da propaganda ficha, 1898.

SaCred Congregation of Rites. Patavina, December 7, 1844, addendum 1. In Ab anno 1706 num. 2163 usque ad annum 1870 num. 3232. Vol. 2 of Decreta autentica Congregationis Sacrorum Rituum ex actis eiusdem collecta eiusque autoritatae promulgata sub auspicii ss. Domini Nostri Leonis Papae XIII, 323. Rome: Typrographia polyglotta S. C. da propaganda ficha, 1898.

SACRED Congregation of Rites. Urbis et Orbis, June 27, 1899. In Ab anno 1871 num. 3233 usque ad annum 1899 num. 4051. Vol. 2 of Decreta autentica Congregationis Sacrorum Rituum ex actis eiusdem collecta eiusque autoritatae promulgata sub auspicii ss. Domini Nostri Leonis Papae XII, 368. Rome: Typrographia polyglotta S. C. da propaganda ficha, 1900.

SACRED CONGREgation of Rites. Urbis, April 8, 1628. In Ab anno 1588 num. 1 usque ad annum 1705 num. 2162. Vol. 1 of Decreta autentica Congregationis Sacrorum Rituum ex actis eiusdem collecta eiusque autoritatae promulgata sub auspicii ss. Domini Nostri Leonis Papae XIII, 118. Rome: Typrographia polyglotta S. C. da propaganda ficha, 1898.

Congregation for the CAuses of SAINTS. Norme sull'amministrazione dei beni delle cause di beatificazione e canonizzazione, March 10, 2016. AAS 108 (2016), 495-98. No English translation available. Polish translation in "Normy dotyczące administrowania funduszami przeznaczonymi na prowadzenie spraw beatyfikacyjnych i kanonizacyjnych. Reskrypt z audiencji u Papieża z 7.03.2016 r.," trans. Marcin Bider and Henryk Misztal. In Henryk MiszTAL and Lidia FiejDAsZ-BuczeK. Postępowanie kanonizacyjne $w$ diecezji lub eparchii, 273-78. Lublin: Wydawnictwo KUL, 2017.

Congregation for the CAuses of SAints. Regulae Consultationis ad medicos Congregationis de causis Sanctorum [Regulation of the Medical Board of the Congregation for the Causes of Saints], September 23, 2016. AAS 108 (2016): 1004-9. English translation available on https://press.vatican.va/content/salastampa/en/bollettino/pubblico/2016/09/23/160923a.html. Polish translation in "Regulamin Konsulty Medycznej z 23.09.2016 r." Translated by Marcin Bider. In Henryk MiszTAL and Lidia FIEJDASZ-BuczeK, Postępowanie kanonizacyjne $w$ diecezji lub eparchii, 321-28. Lublin: Wydawnictwo KUL, 2017.

CONGREgation FOR THE CAUSES OF SAINTS. Sanctorum Mater. Istruzione per lo svogimento delle Inchieste diocesane o eparchiali nelle Cause dei Santi [Instruction "Sanctorum Mater" For Conducting Diocesan or Eparchial Inquiries in the Causes of Saints], December 16, 2006. AAS 99 (2007), 465-512. English translation available on http://www.causesanti.va/content/ causadeisanti/it/documenti/sanctorum-mater_en.html. Polish translation in Henryk MiszTAL. „Sanctorum Mater”. Instrukcja Kongregacji Spraw Kanonizacyjnych o prowadzeniu dochodzenia diecezjalnego lub eparchialnego w sprawach kanonizacyjnych. Komentarz. 2nd ed. Lublin: Wydawnictwo KUL, 2011.

Congregation for the CAuses of SAINTs. Le Reliquie nella Chiesa: Autenticità e Conservazione [Relics in the Church: Authenticity and Preservation]. Bollettino, December 16, 2017. English translation available on http://www.vatican.va/roman_curia/congregations/csaints/documents /rc_con_csaints_doc_20171208_istruzione-reliquie_en.html.

Congregation for the Causes of Saints. Le Cause dei Santi. Sussidio per lo Studium. Edited by Vincenzo Criscuolo, Carmelo Pellegrino, and Robert Sarno, preface by Angelo Amato. $4^{\text {th }}$ ed. Vatican City: Libreria Editrice Vaticana, 2018. 


\section{CASE Law}

Decision of the Supreme Court of 13 January 1965, file ref. no. CR 464/64, LEX no. 259.

\section{LITERATURE}

BARTOSZEWSKI, Gabriel. "Ekshumacja i kanoniczne rozpoznanie doczesnych szczątek sługi Bożego w świetle Instrukcji Kongregacji Spraw Kanonizacyjnych 'Sanctorum Mater'.” In O Sanctorum Mater, edited by Wiesław Bar and Lidia Fiejdasz, 88-118. Lublin: Stowarzyszenie Kanonistów Polskich, 2008.

BARTOSZEwSKI, Gabriel. "Ekshumacja i zabezpieczenie doczesnych szczątków sług Bożych.” In Kult relikwii, edited by Szczepan T. Praśkiewicz. Vol. 11 of Świętość Kanonizowana, 39-59. Kraków: Wydawnictwo Karmelitów Bosych, 2013.

CRiscuolo, Vincenzo. "Praenotatio Relatoris Generalis." In Congregation for the CAuses of SAINTs. Peorien. Beatificationis et Canonizationis Servi Dei Fulton Ioannis Sheen Archiepiscopi Titularis Neoportensis Episcopi Roffensis in America (1895-1979), Positio super vita, virtutibus et fama sanctitatis, vol. 1, pp. I-VI. Rome: Tipografiia Nova ReS s.r.1., 2011.

DARMOROST, Elżbieta. Ustawa o cmentarzach i chowaniu zmartych. Komentarz. Warszawa 2014, LEX/el.

FIEJDASz, Lidia. "Kształtowanie się pojęcia relikwii: aspekt prawny." In Kult relikwii, edited by Szczepan T. Praśkiewicz. Vol. 11 of Świętość Kanonizowana, 17-38. Kraków: Wydawnictwo Karmelitów Bosych, 2013.

"La santitá nel mondo di oggi. Presentata l'esortazione apostolica «Gaudete et exsultate»." L'Osservatore Romano, April 9-10, 2018, p. 1.

MisZTAL, Henryk, and Lidia FIEJDASZ-BuCZEK. Postępowanie kanonizacyjne $w$ diecezji lub eparchii. Lublin: Wydawnictwo KUL, 2017.

MiszTal, Henryk. Prawo kanonizacyjne. Instytucje prawa materialnego, zarys historii, procedura. $2^{\text {nd }}$ ed. Lublin: Wydział Prawa, Prawa Kanonicznego i Administracji KUL, Sandomierz: Wydawnictwo Diecezjalne, 2003.

PAlazzini, Pietro. "Le congregazione romane." In La Curia Romana nella Cost. Ap. «Pastor Bonus», edited by Piero Antonio Bonnet and Carlo Gullo, 309-29. Vatican City: LEV, 1990.

PARTYK, Aleksandra. Pierwszeństwo osób wymienionych w art. 10 ust. 1 ustawy o cmentarzach $i$ chowaniu zmartych, do pochówku zwłok w określonym grobie oraz do ekshumacji, LEX/el., 2014.

SCĄBER, Andrzej. "Rozpoznanie i zabezpieczenie doczesnych szczątków sług Bożych oraz pobranie relikwii w procedurze beatyfikacyjnej-instrukcje Kongregacji Spraw Kanonizacyjnych i procedura.” In Kult relikwii, edited by Szczepan T. Praśkiewicz. Vol. 11 of Świętość Kanonizowana, 72-91. Kraków: Wydawnictwo Karmelitów Bosych, 2013. 


\section{THE CONCEPT OF RELICS AND CANONICAL RECOGNITION, TRANSFER AND PRESERVATION OF THE MORTAL REMAINS OF SERVANTS OF GOD ACCORDING TO THE INSTRUCTION OF THE CONGREGATION FOR THE CAUSES OF SAINTS OF 8 DECEMBER 2017}

\section{Summary}

For the first time since the reform of canon law in 1983, the terminology regarding relics was included in an official document of the Holy See. The Instruction distinguishes between significant and non-significant relics. Referring to the decrees of the Sacred Congregation of Rites, it shows the reasons why this particular division was rightly introduced. The bishop of the diocese or eparchy where the mortal remains are preserved is competent to perform all the possible procedures on them, provided he has previously obtained the consent of the heirs and the consent of the Congregation for the Causes of Saints (different variants are possible). Apart from a tribunal, the bishop nominates expert pathologists to perform technical procedures and two witnesses. The article discusses the procedures of canonical recognition of the remains, extraction of fragments in case of the imminent beatification, and some final operations.

Key words: beatification process; canonization law; postulator; significant relics; non-significant relics; Pope Francis; cult of the relic.

Translated by Tomasz Pałkowski

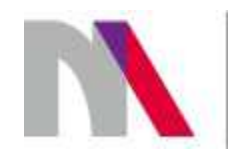

The preparation of the English version of Roczniki Nauk Prawnych (Annals of Iuridical Sciences) and its publication in electronic databases was financed under contract no. 836/PDUN/2018 from the resources of the Minister of Science and Higher Education for the popularization of science. 